\title{
38. TEMPERATURE DATA FROM THE MEXICO DRILLING AREA: REPORT ON LOGGING AND INHOLE TEMPERATURE EXPERIMENTS ${ }^{1}$
}

\author{
Thomas H. Shipley, Scripps Institution of Oceanography, La Jolla, California \\ and \\ Les E. Shephard, College of Geosciences, Texas A\&M University, College Station, Texas
}

\section{INTRODUCTION}

An extensive program of inhole geophysical measurements, implementing the Gearhart-Owen logging package and Uyeda temperature probe, was planned in support of the drilling program. These measurements were designed to aid in predicting in situ physical property variations of lower, middle, and upper slope sediments. Correlation of these variations with the extensive seismic reflection grid would aid in interpreting sediment response to the dynamic effects of subduction. In situ temperature measurements may help to substantiate the gas hydrate reflection as the phase boundary between hydrated and nonhydrated sediments.

Unfortunately, Murphy's laws prevailed, and equipment malfunctions related to sand in the bit release mechanism thwarted our attempt to release the bit and $\log$ the open hole at all sites. In addition, incorrect assembly of the Uyeda tool and related bottom latching problems degraded part of the temperature data collected with this device.

\section{UYEDA TEMPERATURE PROBE}

Inhole temperature measurements on the Glomar Challenger are made by lowering an Uyeda-designed probe into the hole in place of the inner core barrel. The probe is inserted into the sediment ahead of the bit and allowed about 20 minutes to approach equilibrium. The water temperature is measured at the seafloor during each run. Thermistor accuracy is better than $0.1^{\circ} \mathrm{C}$, but overall accuracy because of nonequilibrium conditions within the open hole and pipe is probably about $0.5^{\circ} \mathrm{C}$ (see Erickson et al., 1979, for a more detailed description of the probe).

Table 1 summarizes the attempts to measure the inhole temperatures with the Uyeda Probe at Sites 488, 490 , and 491. None of the curves presented in Figure 1 are completely typical. The closest to a normal curve is Figure 2 at 227.5 meters sub-bottom. Some electronic malfunctions occurred, but the biggest problem was related to incorrect latching of the tool and consequent difficulty in maintaining the probe in the sediments. Because of the erratic nature of many of the curves and wide range of thermal gradients, we do not have confidence in the calculated thermal gradients.

\footnotetext{
${ }^{1}$ Initial Reports of the Deep Sea Drilling Project, Volume 66.
}

\section{GEARHART-OWEN LOGGING}

Logging was attempted at two sites, even though we were unable to release the bit. At Site 492 gamma ray, neutron, and temperature logs were attempted through the pipe. At Site 493 we logged temperature in the open hole by passing the log out the center of the bit (Fig. 2).

At Site 492 all measurements were conducted through the steel pipe. The neutron log malfunctioned. The gamma ray $\log$ is difficult to interpret because of the various pipe joints, drill collars, and bumper subsections. The temperature log was operated between 29 meters and 229 meters sub-bottom about 11 hours after circulation ended and a temperature gradient of $2.2^{\circ} \mathrm{C} /$ $100 \mathrm{~m}$ was computed. Several minor slope changes occur on the temperature-depth plot below 170 meters. Their significance is difficult to assess because we are measuring the temperature of the seawater in the drill pipe, which is disturbed by convection and heating from below. The thermal gradient from this site in the accretionary zone is probably the minimum value and seems more reliable than the Uyeda Probe.

On the continental crust, Site 493 , we attempted to pass the logging temperature tool through the bit and log the temperature of the open hole. The hole partially collapsed and we were able to log only about 35 meters of the hole 4 hours after circulation had ended. The logging yields a thermal gradient of $3.2^{\circ} \mathrm{C} / 100 \mathrm{~m}$.

\section{CONDUCTIVITY}

Thermal conductivity measurements were attempted at Site 490 . Needle probes normally used to measure conductivities of soft sediment were not available, so sediment slabs were used. Repetitive measurements in a diatomaceous mud at 85.82 meters yielded values between 2.2 and $2.9 \mu \mathrm{cal} / \mathrm{cm} \mathrm{s}^{\circ} \mathrm{C}$ ( 2.7 average). Repetitive measurements in a mudstone at 232.83 meters gave values between 2.2 and $3.1 \mu \mathrm{cal} / \mathrm{cm} \mathrm{s}^{\circ} \mathrm{C}$ ( 2.6 average). Such conductivities suggest very high heat flow values. We suspect the conductivities are in error because of the wide range of values in repetitive measurements, probably related to our attempt to use soft sediment slabs.

\section{DISCUSSION}

The results from the inhole temperature measurements are not conclusive. The thermal gradient probably does not vary as much within a single hole as suggested by the measured values (e.g., Site 490). There is 
Table 1. Summary of inhole temperature measurements.

\begin{tabular}{|c|c|c|c|c|c|c|c|}
\hline Hole & Run & $\begin{array}{l}\text { Water } \\
\text { Depth } \\
\text { (m) }\end{array}$ & $\begin{array}{l}\text { Sub-bottom } \\
\text { Depth } \\
\text { (m) }\end{array}$ & $\begin{array}{l}\text { Minimum } \\
\text { Temp. } \\
\left({ }^{\circ} \mathrm{C}\right)\end{array}$ & $\begin{array}{l}\text { Maximum } \\
\text { Temp. } \\
\left({ }^{\circ} \mathrm{C}\right)\end{array}$ & $\begin{array}{l}\text { Minimum } \\
\text { Gradient } \\
\left({ }^{\circ} \mathrm{C} / 100 \mathrm{~m}\right)\end{array}$ & Comments \\
\hline \multirow[t]{3}{*}{488} & 1 & 4254 & - & - & - & - & Electronic malfunction \\
\hline & 2 & & 162.5 & 2.3 & 8.6 & 3.9 & \\
\hline & 3 & & 257.5 & 2.4 & 3.7 & 0.5 ? & Not seated in bottom(?) \\
\hline \multirow[t]{4}{*}{490} & 1 & 1761 & 94.5 & 3.2 & $10.2(?)$ & $7.4 ?$ & Probably not latched and seated \\
\hline & 2 & & 170.5 & 3.1 & $2.3(?)$ & $3.6 ?$ & Probably not latched and seated \\
\hline & 3 & & 189.5 & - & - & - & Water sample \\
\hline & 4 & & 227.5 & 3.1 & 8.7 & 2.5 & Good curve \\
\hline \multirow[t]{3}{*}{491} & 1 & 2883 & - & - & - & - & Electronic malfunction \\
\hline & 2 & & 204.0 & 2.3 & - & - & Did not latch, not seated in bottom \\
\hline & 3 & & 304.5 & 2.3 & 14.5 & 4.0 & \\
\hline $492 \mathrm{~B}^{\mathrm{a}}$ & - & 1942 & $(29-229)$ & $(4.9)$ & (9.4) & 2.2 & Logging through pipe, circulation had ended 11 hrs. earlier \\
\hline $493 \mathrm{~B}^{\mathrm{a}}$ & - & 645 & $(116-150)$ & (14.7) & (15.8) & 3.2 & Logging open hole circulation had ended $4 \mathrm{hrs}$. earlier \\
\hline
\end{tabular}

no good criterion available to separate the three gradients derived from the Uyeda Probe within the accretionary zone $\left(3.9,2.5\right.$, and $\left.4.0^{\circ} \mathrm{C} / 100 \mathrm{~m}\right)$. The curve for the $2.5^{\circ} \mathrm{C} / 100 \mathrm{~m}$ measurement at Site 490 does have the characteristics of a normal run.

The logging run at Site 492 , while in pipe, may give the best gradient, because the log was run 11 hours after circulation had stopped in the hole and run fairly rapidly. We feel the $2.2^{\circ} \mathrm{C} / 100 \mathrm{~m}$ measured over a 200 meter interval may be the best estimate of the thermal gradient in the accretionary zone. The thermal gradient of $3.2^{\circ} \mathrm{C} / 100 \mathrm{~m}$ at Site 493 cannot be considered accurate because it was measured over an interval of only 34 meters.
The thermal gradient of $2.2^{\circ} \mathrm{C} / 100 \mathrm{~m}$ for the accretionary zone is higher than the $1.4^{\circ} \mathrm{C} / 100 \mathrm{~m} 5^{\circ} \times 5^{\circ}$ average of Langseth and Von Herzen (1970), but it does support the conclusion that the bottom-simulating reflection is near the methane hydrate phase boundary (this volume).

\section{REFERENCES}

Erickson, A. J., Avera, W. E. and R. Byrne, 1979. Heat-flow results, DSDP Leg 48. In Montadert, L., Roberts, D. G., et al., Init. Repts. DSDP, 48: Washington (U.S. Govt. Printing Office), 277-288.

Langseth, M. G., and Von Herzen, R. P., 1970. Heat flow through the floor of the world oceans. In Maxwell, A. E. (Ed.), The Sea (Vol. 4): New York (Wiley Interscience), 299-352. 

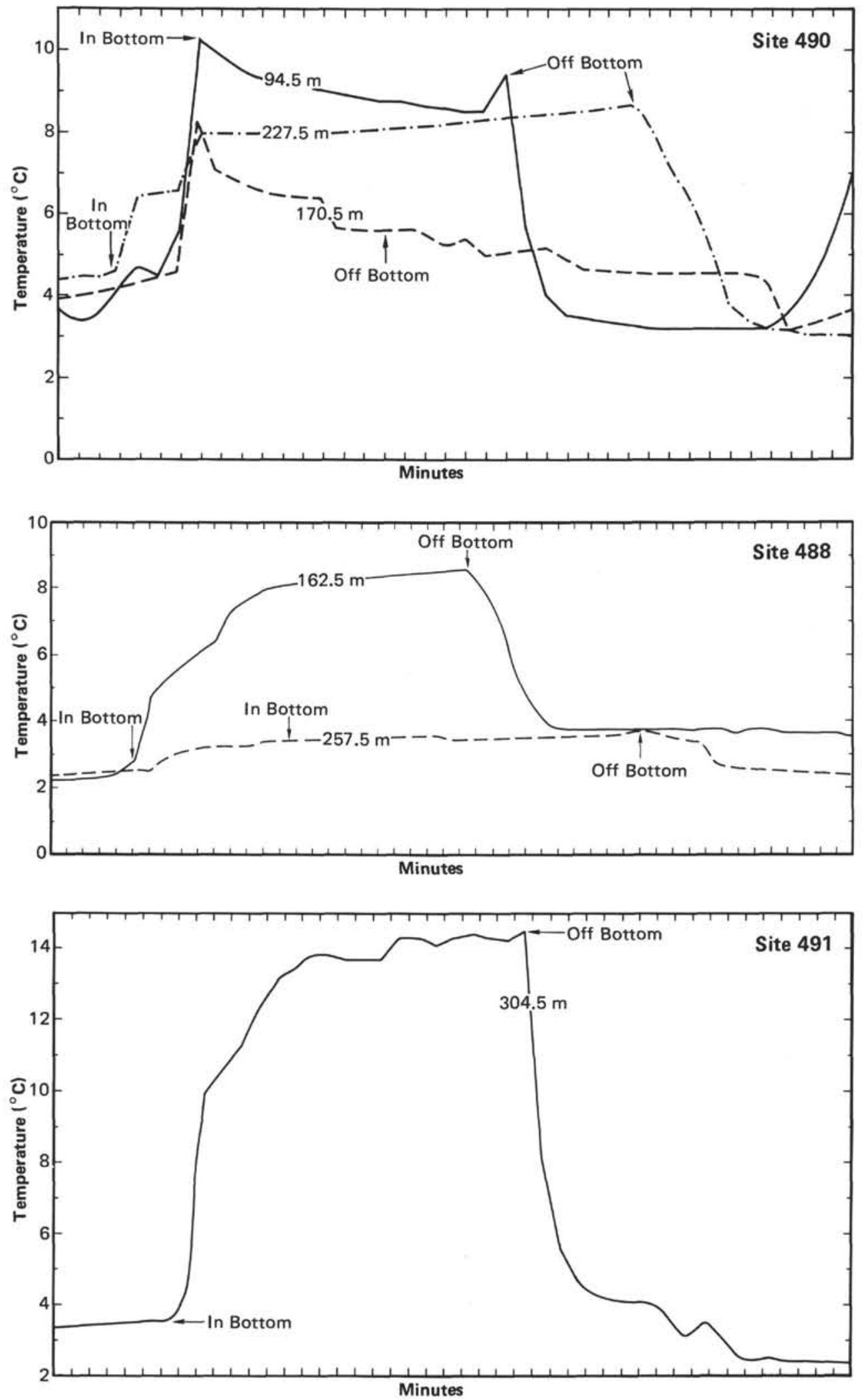

Figure 1. Uyeda temperature probe profiles at Sites 488,490 , and 491. 
T. H. SHIPLEY, L. E. SHEPHARD

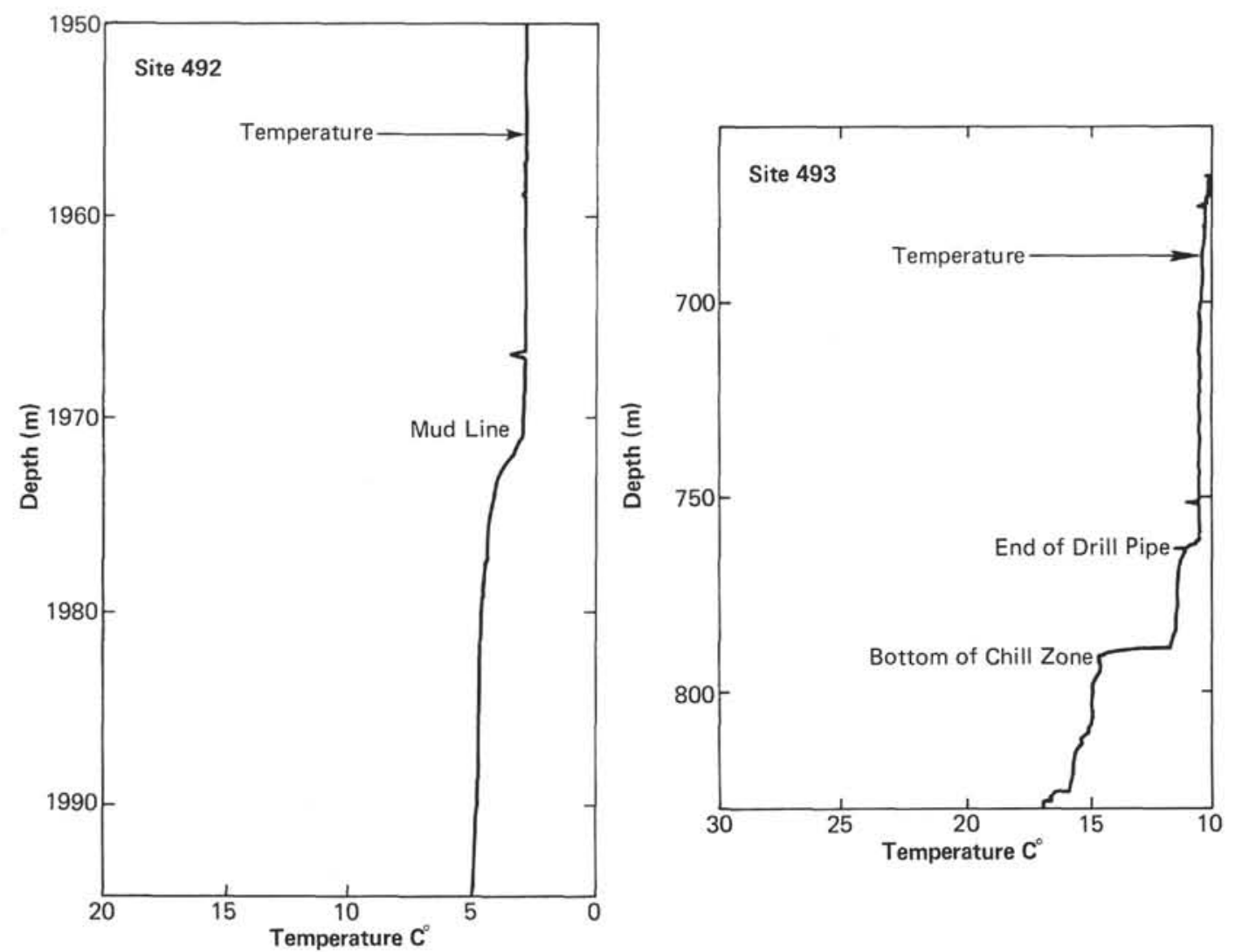

Figure 2. Gearhart-Owen temperature logs at Sites 492 and 493. 